\title{
Relationships between Earth's Rotation or Revolution and Geographical Extent of the Global Surface Monsoons
}

\author{
Mbane Biouele César \\ Laboratory of Earth's Atmosphere Physics, Department of Physics, University of Yaoundé I, Yaoundé, Cameroun \\ Email: cesar.mbane@yahoo.fr
}

Received November 14, 2013; revised December 7, 2013; accepted December 15, 2013

Copyright (C) 2014 Mbane Biouele César. This is an open access article distributed under the Creative Commons Attribution License, which permits unrestricted use, distribution, and reproduction in any medium, provided the original work is properly cited. In accordance of the Creative Commons Attribution License all Copyrights (C) 2014 are reserved for SCIRP and the owner of the intellectual property Mbane Biouele César. All Copyright (C) 2014 are guarded by law and by SCIRP as a guardian.

\begin{abstract}
Monsoon seasons, occasionally also known as wet seasons or trade-wind littoral seasons, are found in the regions where there is a complete seasonal reversal of the prevailing surface winds. Accompanying these shifts in the prevailing surface winds are modulations in rainfall activity. Given the fact that our knowledge of the monsoons is mainly based on the interpretation of the mean values of precipitation, cloudiness and winds; relationships between earth's rotation or revolution and geographical extent of the global surface monsoons deserve to be highlighted. In the abundant literary and audiovisual production devoted to monsoons worldwide and despite the fact that everyone agrees with physical law which shows that Coriolis force acts to the right in the northern hemisphere (to the left in the southern hemisphere), there is no reference to the relationship between Coriolis force (due to earth's rotation) effects on troposphere general circulation and geographical extent of the global surface monsoons. Furthermore knowing that the ITCZ oscillations on either side of the equators (due to earth's revolution) determine the seasons (mainly winter and summer), it is clear that earth's revolution also plays a crucial role in the seasonal reversal of the prevailing surface winds observed in the regions where monsoons are found. Our main objective is to provide a rational answer to the question: what is a monsoon?
\end{abstract}

\section{KEYWORDS}

Seasonal Reversal of the Prevailing Surface Winds; Coriolis Force; Earth's Rotation; ITCZ (Inter-Tropical Convergence Zone) Oscillations; Earth's Revolution

\section{Introduction}

The monsoons influence the climates of India, Bangladesh, Southeast Asia, and, to a lesser extent, northern Australia and Central Africa. They are found in those regions where there is a complete seasonal reversal of easterly (or westerly) winds. Despite the interest shown by scientists in monsoons [1-20], many questions remain about the physical processes capable of generating complete seasonal reversal of the prevailing surface winds. In this work we want to develop a better description of the relationship between earth's rotation-revolution with respect to sun and geographical extent of the global surface monsoons. In our previous work [21-24], we deduce from Clausius-Clapeyron relation derived in 1832 that, unlike the dry water vapor that can be assimilated to the ideal gas at all circumstances, the saturated water vapor has, in an air parcel at the same time very cold (temperatures below $0.0098^{\circ} \mathrm{C}$ ) and rich in moisture (vapor pressure above $6.11 \mathrm{mb}$ ), thermoelastic properties diametrically opposed to those of ideal gas (including dry water vapor). I.e., the two equal level surfaces of water vapor and temperature rating respectively at $6.11 \mathrm{mb}$ and $0.0098^{\circ} \mathrm{C}$ separate clearly parts of the troposphere where ideal gas assumption can be applied without too distort reality to parts of the troposphere where this assumption is banned. Therefore, everyone can now easily note with satisfaction that the presence of water substance in all three states in the earth's atmosphere gives to troposphere the exclusivity of a General Circulation consisting of three groups of passive convective cells (Hadley, Ferrel, and Polar) on either side of the ITCZ. Knowing that the ITCZ oscillations on either side of the equators 
due to earth's revolution determine the hemisphere's seasons (mainly winter and summer), it is clear that earth's revolution plays a crucial role in the seasonal reversal of the prevailing surface winds observed in the regions where monsoons occur. Our results will mainly be based on representation in either side of the ITCZ of the seasonal prevailing surface winds triggered by Coriolis force effects on Hadley, Ferrel and Polar cells.

\section{Troposphere General Circulation Based on Atmosphere Dynamic Balance}

\subsection{Troposphere Dynamic Balance}

Atmosphere dynamics uses precise concept of air particle [25-27]. Especially:

1) Few exchanges on molecular scale: it is easy to follow quantity of air which preserves certain properties.

2) Quasi-static equilibrium: at any moment there is dynamic balance, i.e., the particle has the same pressure as its environment $\left(P=P_{e x t}\right)$.

3) No thermal balance: heat transfers by conduction are very slow and neglected. One can have $T \neq T_{\text {ext }}$.

4) The horizontal sizes of the air particle can go from a few $\mathrm{cm}$ to $100 \mathrm{~km}$ according to the applications.

Taking into account the fact that the atmosphere is mainly composed of dry air and water vapor, the Dalton's law connects the pressure $(P)$ with the partial pressure of dry air $\left(P_{a}\right)$ and saturated water vapor $\left(e_{w}\right)$

$$
P=P_{a}+e_{w}
$$

In deriving $(P)$ with respect to the temperature, one has

$$
\frac{\mathrm{d} P}{\mathrm{~d} T}=\left(\frac{\partial P}{\partial T}\right)_{V}+\left(\frac{\partial P}{\partial V}\right)_{T}\left(\frac{\mathrm{d} V}{\mathrm{~d} T}\right)
$$

According to the Quasi-static equilibrium (or dynamic balance) the pressure of the parcel of air must be the same as that of the ambient air, including during sudden local changes in phases by water contained in this parcel. Reality that all meteorologists restore through the following famous sentence: the phases change takes place at constant pressure. Thereby write Equation (3),

$$
\mathrm{d} P=0
$$

Equations (2) and (3) lead to the derivative of $V$ compared to $T$

$$
\frac{\mathrm{d} P}{\mathrm{~d} T}=-\frac{\left(\frac{\partial P}{\partial T}\right)_{V}}{\left(\frac{\partial P}{\partial V}\right)_{T}}
$$

Introducing the coefficient of thermal expansion of moist air at constant temperature

$$
\chi=-\frac{1}{P}\left(\frac{\partial P}{\partial T}\right)_{V}
$$

Then the Fundamental Relationship of Atmosphere Dynamic Balance:

$$
\frac{\mathrm{d} V}{\mathrm{~d} T}=\frac{1}{\chi} \cdot \frac{1}{P}\left(\frac{\partial P}{\partial T}\right)_{V}
$$

One can also write equation of Atmosphere dynamic balance in terms of partial pressures

$$
\frac{\mathrm{d} V}{\mathrm{~d} T}=\frac{1}{\chi} \cdot \frac{1}{P}\left[\left(\frac{\partial P_{a}}{\partial T}\right)_{V}+\left(\frac{\partial e_{w}}{\partial T}\right)_{V}\right]
$$

Or,

$$
\frac{\mathrm{d} V}{\mathrm{~d} T} \cong \frac{1}{\chi} \cdot \frac{1}{P}\left[\left(\frac{\partial e_{\mathrm{w}}}{\partial T}\right)_{V}\right]
$$

Relations (6) and (7) lead to a very important atmosphere Dynamics statement:

At any moment and throughout the atmosphere, one can use Equations (6) or (7) and Clausius-Clapeyron slope of the equilibrium curves in the eT-plane (Figure 1) to predict in which direction the air parcel will move (up or down) if its temperature increases or decreases. Table 1 and Figure 2 provide an overview of possible situations in the troposphere.

\subsection{Troposphere General Circulation Based on Moist Air Dynamic Balance}

The two equal level surfaces of water vapor and temperature rating respectively at $6.11 \mathrm{mb}$ and $0.0098^{\circ} \mathrm{C}$ (Figure 2) separate clearly parts of the troposphere where ideal gas assumption can be applied without too distort reality to parts of the troposphere where this assumption is banned: hence appropriate and unique plots of earth's atmosphere tricellular circulation (Figure 3).

\section{Coriolis Force Effects on Troposphere General Circulation}

Coriolis force is everywhere perpendicular to the relative

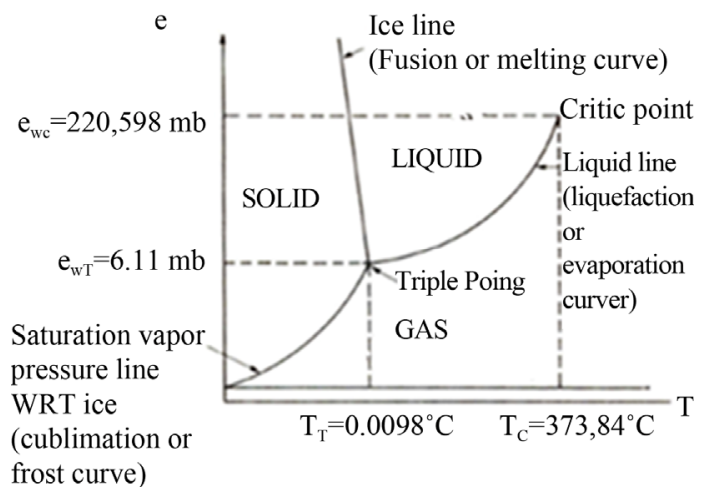

Figure 1. Saturation curves for water substance onto the eT-plane $\left(e_{w T}\right.$ and $T_{T}$ are triple-point coordinates): $e_{w T}=$ $6.11 \mathrm{mb} ; T_{T}=0.0098^{\circ} \mathrm{C}$. 
Table 1. Pressure variation of a constant volume of moist air, depending on the temperature $T$ : in specific regions of the Troposphere, delimited by equal level surfaces rating respectively at $0.0098^{\circ} \mathrm{C}$ and $6.11 \mathrm{mb}$.

\begin{tabular}{|c|c|c|c|}
\hline Range of Temperature coupled with Range of humidity & $\begin{array}{l}T<0.0098^{\circ} \mathrm{C} \\
\boldsymbol{e}_{w}<6.11 \mathrm{mb} \\
\end{array}$ & $\begin{array}{l}T<0.0098^{\circ} \mathrm{C} \\
\boldsymbol{e}_{w}>6.11 \mathrm{mb}\end{array}$ & $\begin{array}{l}T>0.0098^{\circ} \mathrm{C} \\
e_{w}>6.11 \mathrm{mb}\end{array}$ \\
\hline$\left(\frac{\partial P}{\partial T}\right)_{V}$ & + & - & + \\
\hline$\frac{\mathrm{d} V}{\mathrm{~d} T}$ & + & - & + \\
\hline
\end{tabular}

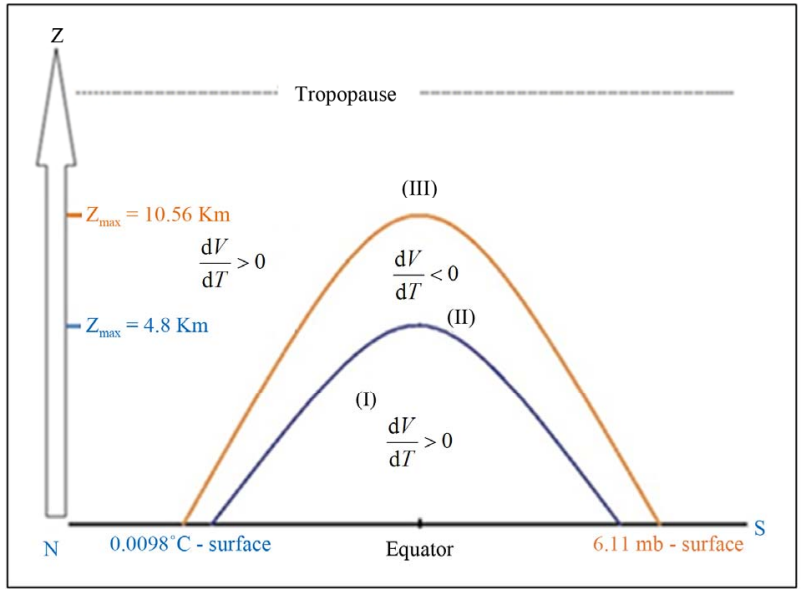

Figure 2. Troposphere specific regions depending on the manner in which $V$ changes with $T(V$ and $T$ are respectively volume and temperature of an air parcel): If $(\mathrm{d} V / \mathrm{d} T)>0$ the particle swells when its temperature increases (so it becomes lighter), if $(\mathrm{dV} / \mathrm{d} T)<0$ the particle shrinks when its temperature increases (so it becomes less light). $Z_{\max }$ are statistical value of observed maximum elevation of equal level surfaces of temperature and water vapor rating respectively at $0.0098^{\circ} \mathrm{C}$ and $6.11 \times 10^{-3}$ bars.

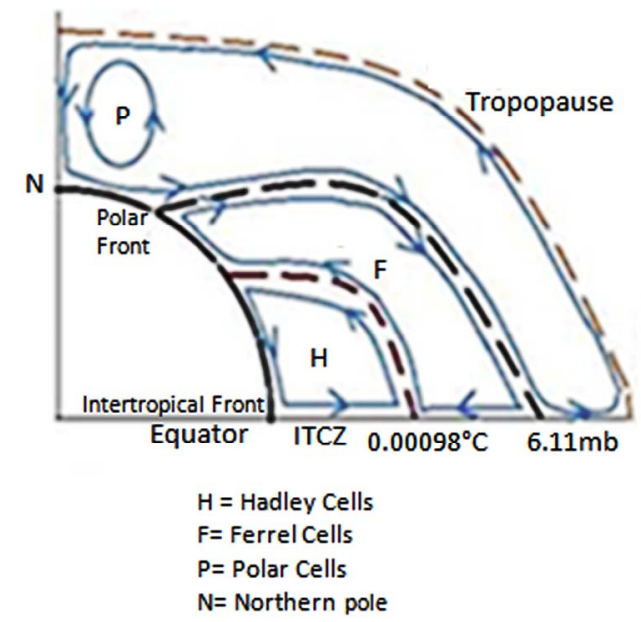

Streamlines of earth's atmosphere general circulation (C. Mbane, 2012)

Figure 3. Schematic representation of the General Circulation, derived from Troposphere dynamic balance.

velocity $\vec{V}_{R}$ (since: $\vec{F}_{C}=-2 \vec{\Omega} \Lambda \vec{V}_{R}$, in Meteorology Rectangular Coordinates System), and it acts to the right (left) in the northern (southern) hemisphere. Therefore, each cell of Figure 3 must be behind the formation of easterly-westerly couple of winds as shown on Figure 4. When the ITCZ is positioned along the equator, Coriolis force acts on the Hadley and Polar cells and produces surface Easterly winds (E) while at the same time it acts on the Ferrell cells and generates surface Westerly winds (W) as summarized on our Figure 5(a) and on the commonly known Figure 5(b). In our work, we want to understand what happens exactly when the ITCZ moves to the northern hemisphere and then the $2^{\text {nd }}$ Hadley cells cross the equator. At that time Coriolis force acts on the $2^{\text {nd }}$ Hadley cells and generates surface southern westerly winds [named in this paper: SE2W (Southern Equatorial Westerly Winds)] in regions firstly occupied by Trade Winds (Figures 6(a) and (b)). During Northern Hemisphere's winter, the ITCZ moves in the Southern hemisphere and then the $1^{\text {st }}$ Hadley cells cross the equator and gives rise to surface northern westerly winds [named by us: NE2W (Northern Equatorial Westerly Winds)] in regions located between the equator and the ITCZ and firstly occupied by Trade Winds (Figures 7(a) and (b)). To summarize: Anyone who wants to understand the weather factors which drive the formation of monsoons must remember that these rainfalls phenomena occur in regions where seasonal reversals can be performed by Trade Winds, SE2W, NE2W, HL2W (Horse Latitudes westerly winds) and PLEW (Polar Latitudes Easterly Winds) as summarized in geographical extent of the global surface monsoons [28]. That means typically: both latitudes within extreme positions in summer (Figure 6(a)) and winter (Figure 7(a)) of the equal vapor pressure surface rating at $6.11 \mathrm{mb}$. In the case of tropical monsoons, seasonal reversals are performed in the northern and southern hemispheres by (Trade Winds; SE2W) and (Trade Winds; NE2W) couples respectively (Figure 8).

\section{Conclusions and Comments}

In the northern hemisphere, the sun declination reaches its extreme values on June and July: it is precisely during this period that the monsoon rains are most abundant. This shows that there is a closely relationship between the two climatic factors that are the sun declination (which is aligned on the ITCZ, with a slight phase delay) and 


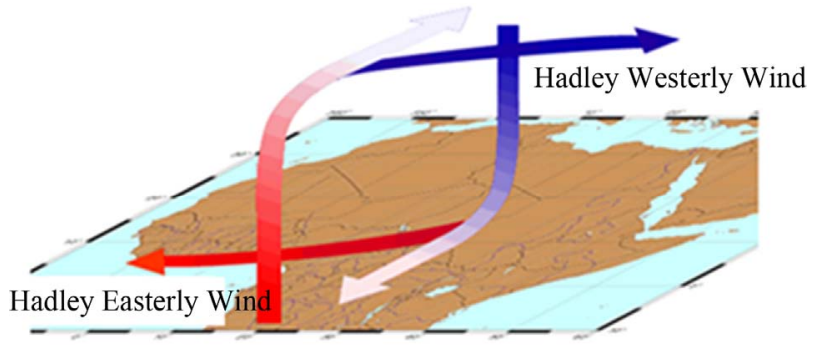

Easterly and Westerly winds triggered by Coriolis force acting on the Hadley Cell

Figure 4. Easterly and Westerly winds triggered by Coriolis force acting on the Hadley Cell.

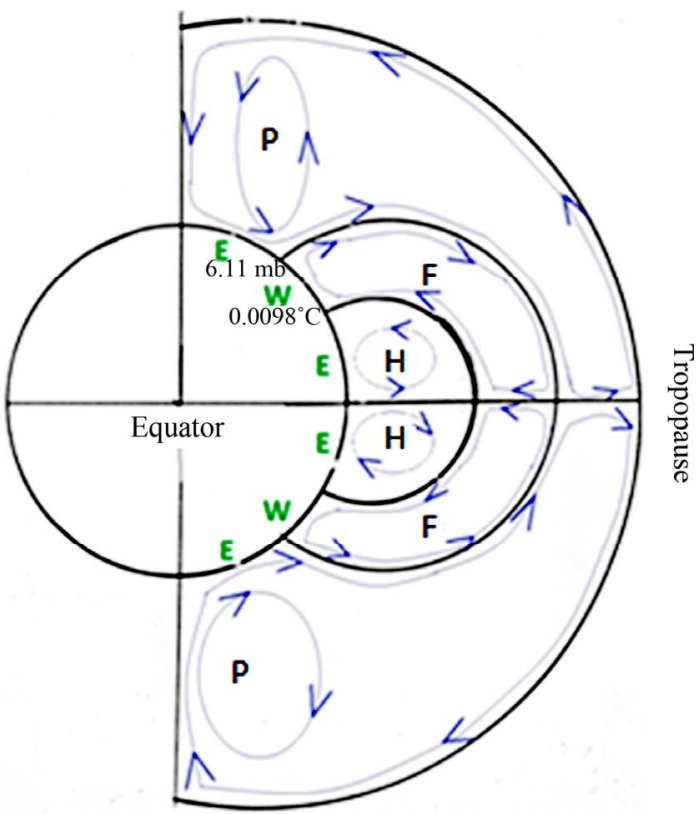

(a)

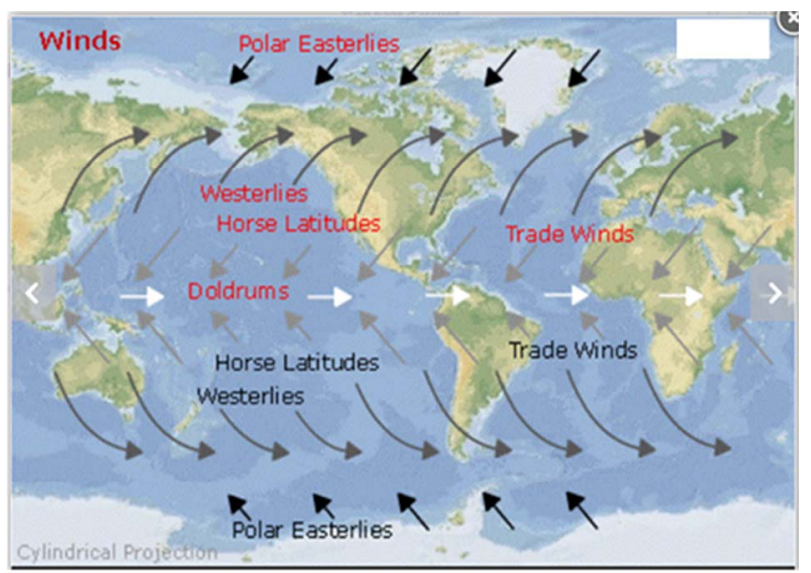

Geographical distrilution of surface prevailing wihds when the ITCZ (white darts) conincides with the equator

(b)

Figure 5. (a) Schematic localization of prevailing surface winds ( $E=$ Easterlies, $W=$ Westerlies) when the ITCZ is positioning along the equator; (b) Worldwide Geographical Extent of the prevailing surface winds when the ITCZ is positioning along the equator.

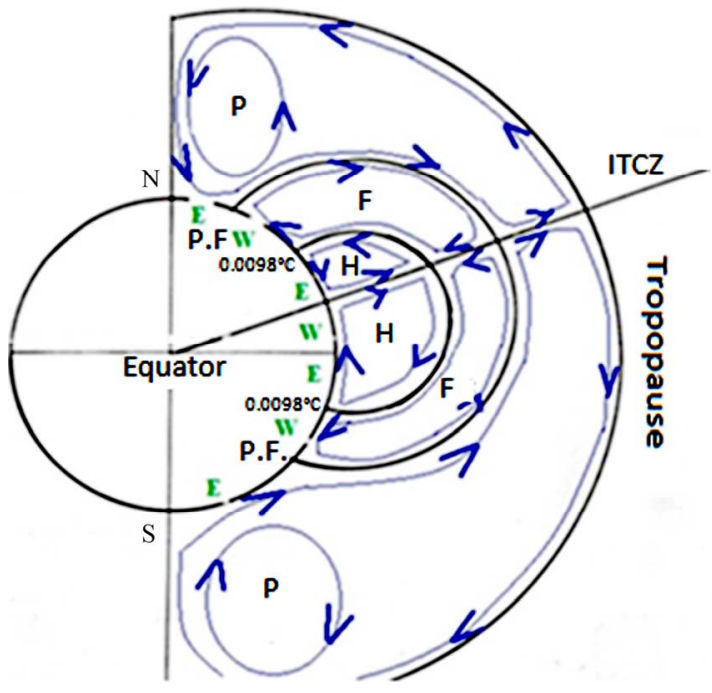

(a)

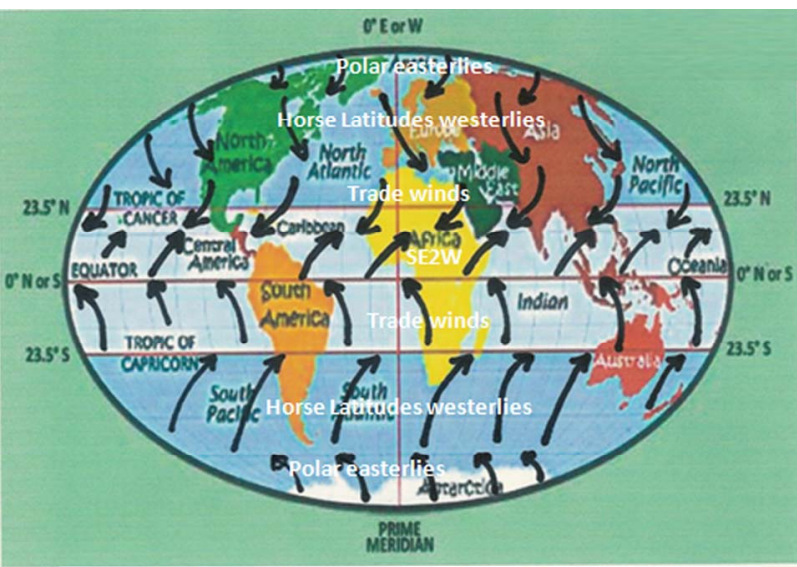

Geographical Extent of the prevailing surface winds in summer. One may find (7) profiles instead of (6) commonly known: Polar easterlies (2), Horse latitudes westerlies (2), Trade winds (2) and SE2W [Southern Equatorial Westerly winds] (1)

(b)

Figure 6. (a) Schematic localization of prevailing surface winds in summer: with respect to Northern hemisphere; (b) Worldwide Geographical Extent of the prevailing surface winds in summer: with respect to Northern hemisphere.

monsoon rainfall intensity. Whether the Northern Hemisphere or Southern Hemisphere, monsoons are weather phenomena closely associated with the earth's rotation effects on general circulation of the troposphere and ITCZ oscillations performed by earth's revolution. Monsoon precipitation intensity also depends on the proximity of oceans or sees whose are heat reservoirs capable of producing water vapor even at night due to liquid water inertia. Monsoon is then characterized by hot and particularly wet surface winds that are as tropical wet climates or tropical and trade-wind littoral climates. Therefore it is necessary to avoid confusing monsoons, of which time scales (several decades) are comparable to those of the general circulation, with sees breezes of much smaller 


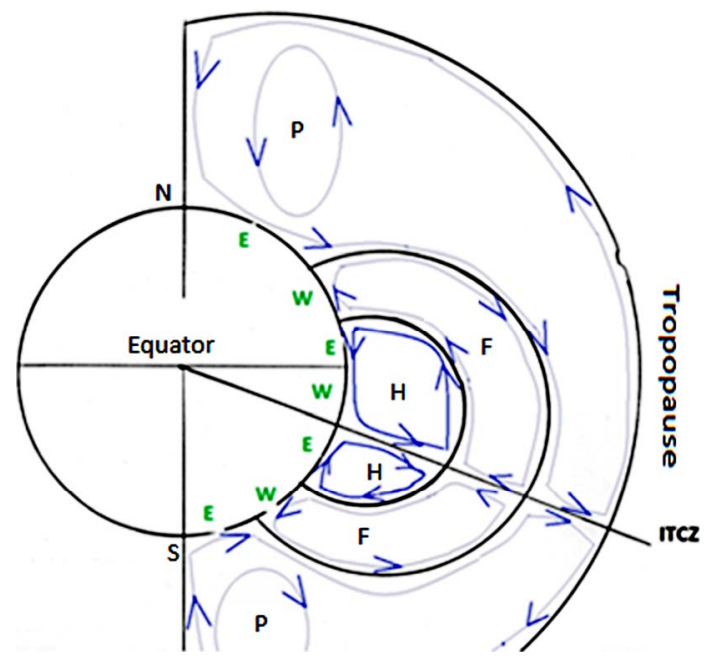

(a)

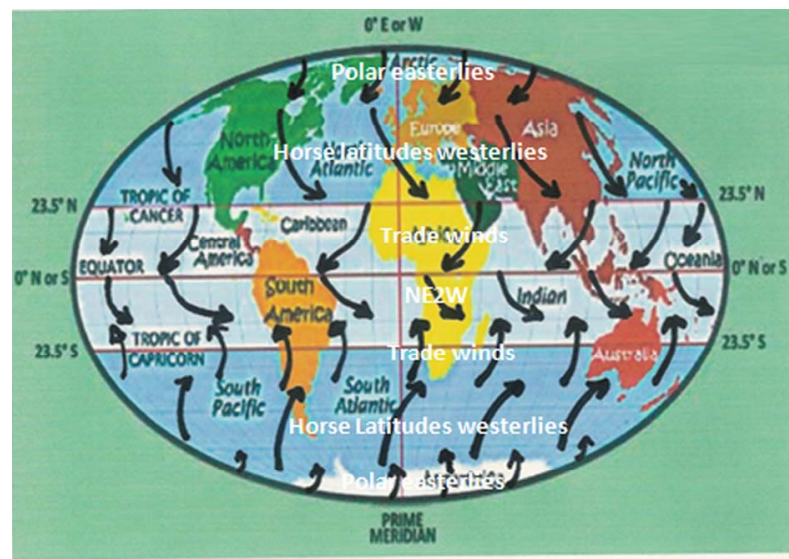

Geographical Extent of the prevailing surface winds in winter. One can find (7) profiles instead of (6) commonly known: Polar easterlies (2), Horse latitudes westerlies (2), Trade winds (2) and NE2W [Northern Equatorial Westerly winds] (1)

(b)

Figure 7. (a) Schematic localization of prevailing surface winds in winter: with respect to Northern hemisphere; (b) Worldwide Geographical Extent of the prevailing surface winds in winter: with respect to Northern hemisphere.

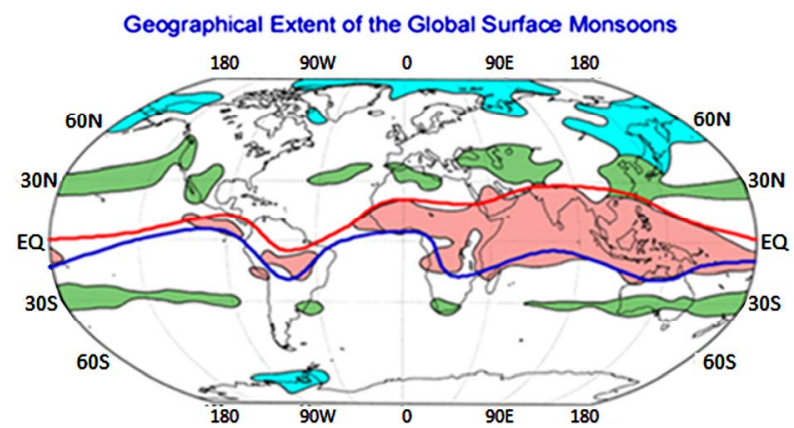

The red, green, and blue areas indicate the tropical, subtropical, and temperatefrigid monsoons, respectively. The red and blue thick lines represent the ITCZ in summer and in winter, respectively (J. G. Charney and J. Shuida, 1981).

Figure 8. Geographical extend of the global surface Monsoons. time scales (less than 12 hours). At the African NorthWest Littoral, the SE2W (revealed by this paper) which replace the traditional Trade Winds (called Harmattan by west Africans), announce the arrival of the West African monsoon that takes place during northern hemisphere's summer. At the northern west littorals (e.g., European littorals), our SE2W combine favorably with sea breezes: the resulting precipitations are therefor persistent and abundant. While on the northern east littorals, our SE2W prevent sea breezes and considerably reduce the frequencies of sea breezes' precipitations. At night, the SE2W dominate the continental breezes in west littorals while in the east littorals, the SE2W and continental breezes combine favorably. In summary, the limiting factors for monsoon rainfall are: distance from the moisture sources such as the oceans, distance from the main source of heat which is the sun (that means solar activity), low penetration of the ITCZ in the northern or southern hemisphere (that means: low height of monsoon), small size of the water vapor source. Within Horse latitudes, Trade winds brought wet climates to eastern littorals while SE2W brought wet climates to only parts of the western littorals crossed by the ITCZ. Intensity of precipitations, as a result, mainly depends on the width of the ocean which moistens the trade winds or the SE2W.

\section{REFERENCES}

[1] R. G. Ashrit, A. Kitoh and S. Yukimoto, "Transient Response of ENSO-Monsoon Teleconnection in MRICGCM2.2 Climate Change Simulations," Journal of the Meteorological Society of Japan, Vol. 83, No. 3, 2005, pp. 273-291. http://dx.doi.org/10.2151/jmsj.83.273

[2] S. Battacharya and R. Narasimha, "Possible Association between Indian Mosoon Rainfall and Solar Activity," Geophysical Research Letters, Vol. 32, No. 5, 2005, Article ID: LO5813.

http://dx.doi.org/10.1029/2004GL021044

[3] B. Couanang Siebatcheu, C. Mbane Biouele and J. S. Eyebe Fouda, "Atmosphere Dynamic Balance Model (ADB-Model) and Related Troposphere General Circulations' Cells behind the Formation of Tropical Monsoons," Archive of Physiology Research, Vol. 3, No. 2, 2012, pp. 93-100.

[4] S. K. Dash, J. R. Kumar and M. S. Shekhar, "On the Decreasing Frequency of Mosoon Depressions over the Indian Region," Science Curriculum, Vol. 86, 2004, pp. 1404-1411.

[5] B. N. Goswani, V. Venugopal, D. Sengupta, M. S. Madhusoodanan and P. K. Xavier, "Increasing Trend of Extreme Rain Events over India in a Warming Environment," Science, Vol. 314, No. 5804, 2006, pp. 1442-1445. http://dx.doi.org/10.1126/science.1132027

[6] S. Hastenrath, "In Search of Zonal Circulations in the Equatorial Atlantic Sector from the NCEP-NCAR Reanalysis," International Journal of Climatology, Vol. 21, No. 1, 2001, pp. 37-48. http://dx.doi.org/10.1002/joc.597 
[7] S. Janicot, A. Harzallah, B. Fontaine and V. Moron, "West African Monsoon Dynamics and Eastern Equatorial Atlantic and Pacific SST Anomalies (1970-88)," Journal of Climate, Vol. 11, No. 8, 1998, pp. 1874-1882. http://dx.doi.org/10.1175/1520-0442-11.8.1874

[8] M. R. Jury and B. Pathack, "Composite Climatic Patterns Associated with Extreme Modes of Summer Rainfall over Southern Africa: 1975-1984," Theoretical and Applied Climatology, Vol. 47, No. 3, 1993, pp. 137-145. http://dx.doi.org/10.1007/BF00867446

[9] J. P. McCreary, P. K. Kundu and R. Molinari, "A Numerical Investigation of the Dynamics and Thermodynamics and Mixed Layer Processes in the Indian Ocean," Progress in Oceanography, Vol. 31, No. 3, 1993, pp. 181244. http://dx.doi.org/10.1016/0079-6611(93)90002-U

[10] S. D. Meyers, B. G. Kelley and J. J. O’Brien, “An Introduction to Wavelet Analysis in Oceanography and Meteorology: With Application to the Dispersion of Yanai Waves," Monthly Weather Review, Vol. 121, No. 10, 1993, pp. 2858-2866.

http://dx.doi.org/10.1175/1520-0493(1993)121<2858:AIT $\mathrm{WAI}>2.0 . \mathrm{CO} ; 2$

[11] E. J. Mpeta and M. Jury, "Intra-Seasonal Convective Structure Evolution over Tropical East Africa," Climate Research, Vol. 17, No. 1, 2001, pp. 83-92. http://dx.doi.org/10.3354/cr017083

[12] K. Muni Krishna, "Intensifying Tropical Cyclones over the North Ocean during Summer Monsoon-Global Warming," Global and Planetary Change, Vol. 65, No. 1-2, 2009, pp. 12-16. http://dx.doi.org/10.1016/j.gloplacha.2008.10.007

[13] C. C. Mutai, M. N. Ward and A. W. Colman, "Towards the Prediction of the East Africa Short Rains Based on Sea-Surface Temperature-Atmosphere Coupling," International Journal of Climatology, Vol. 18, No. 9, 1998, pp. 975-998.

http://dx.doi.org/10.1002/(SICI)1097-0088(199807)18:9< 975::AID-JOC259>3.0.CO;2-U

[14] C. J. Reason and H. Mulenga, "Relationships between South African Rainfall and SST Anomalies in the Southwest Indian Ocean," International Journal of Climatology, Vol. 19, No. 15, 1999, pp. 651-1673. http://dx.doi.org/10.1002/(SICI)1097-0088(199912)19:15 $<1651::$ AID-JOC439>3.0.CO;2-U

[15] Y. Richard, "Variability of Rainfall in West Africa," Meteorologie, Vol. 8, 1994, pp. 11-22.

[16] Y. Richard, S. Trzaska, P. Roucon and M. Rouault, "Modification of the Southern African Rainfall Variability/ ENSO Relationship since the Late 1960s," Climate Dynamics, Vol. 16, No. 12, 2000, pp. 883-895. http://dx.doi.org/10.1007/s003820000086

[17] A. Shiller, J. S. Godfrey, P. C. McIntosh, G. Meyers and R. Fiedler, "Interannuel Dynamics and Thermodynamics of the Indo-Pacific Oceans," Journal of Physical Oceanography, Vol. 30, No. 5, 2000, pp. 987-1012.

http://dx.doi.org/10.1175/1520-0485(2000)030<0987:ID ATOT $>2.0 . \mathrm{CO} ; 2$

[18] W. B. White and D. R. Cayan, "A Global El Nino Southern Oscillation Wave in Surface Temperature and Pressure and Its Interdecadal from 1900 to 1997," Journal of Geophysical Research: Oceans, Vol. 105, No. C5, 2000, pp. 11223-11242.

http://dx.doi.org/10.1029/1999JC900246

[19] P. K. Xavier and P. V. Joseph, "Vertical Wind Shear in Relation to Frequency of Monsoon Depressions and Tropical Cyclones of Indian Seas," Proceedings of TROPMET, National Symposium on Ocean and Atmosphere, 2000, pp. 232-245.

[20] J. Yu and Y. Wang, "Response of Tropical Cyclone Potential Intensity over the North Indian Ocean to Global Warming," Geophysical Research Letter, Vol. 36. 2009, Article ID: L03709.

[21] C. Mbane Biouele, "Hurricanes and Cyclones Kinematics and Thermodynamics Based on Clausius-Clapeyron Relation Derived in 1832," International Journal of Physical Sciences, Vol. 8, No. 23, 2013, pp. 1284-1290.

[22] C. Mbane Biouele, E. Yizengaw, M. B. Moldwin and G. Cautenet, "Impacts of Thermoelastic Properties of Saturated Water Vapor on Tropical Depressions Thermodynamics and Dynamics," Scholar Research Library-Archives of Physics Research, Vol. 2, No. 4, 2011, pp. 24-33.

[23] C. Mbane Biouele, "Vertical Profiles of Winds and Electric Fields Triggered by Tropical Storms-Under the Hydrodynamic Concept of Air Particle," International Journal of Physical Sciences, Vol. 4, No. 4, 2009, pp. 242 246.

[24] C. Mbane Biouele, "Physics of Atmosphere Dynamic or Electric Balance Processes such as Thunderclouds and Related Lighting Flashes," Geosciences, Vol. 2, No. 1, 2012, pp. 6-10. http://dx.doi.org/10.5923/j.geo.20120201.02

[25] H. R. Byers, "General Meteorology," McGraw-Hill Book Company. INC, 1959, $540 \mathrm{p}$.

[26] G. K. Batchelor, "An Introduction to Fluid Dynamics," Cambridge University Press, 1967, 496 p.

[27] C. A. Riegel, "Fundamentals of Atmospheric Dynamics and Thermodynamics," World Scientific Publishing Co. Pte. Ltd., 1992, 512 p.

[28] J. G. Charney and J. Shukla, "Predictability of Monsoons," In: J. Lighthill and R. P. Pearce, Eds., Monsoon Dynamics, Cambridge University Press, Cambridge, 1981, pp. 99-108.

http://dx.doi.org/10.1017/CBO9780511897580.009 